\title{
GEOMETRY OF THE LATE GOTHIC PORTAL IN HANDLOVÁ CHURCH
}

\author{
Zuzana GRÚŇOVÁ ${ }^{1, *}$ \\ ${ }^{1}$ Department of Building Engineering and Urban Planning, Faculty of Civil Engineering, University of \\ Žilina, Univerzitná 8215/1, 01026 Žilina, Slovakia. \\ corresponding author: grunova@fstav.uniza.sk.
}

\section{Abstract}

Gothic architecture is one of the oldest surviving architecture in Slovakia. The Church of St Catherine of Alexandria in Handlová was built in the High Gothic period of 1360 - 1370; its main stone portal belongs to the later phase of 1502 . The paper focuses on architectural features and geometry of this late gothic portal. The portal has a geometrical construction clearly based on the square of $2670 \times 2670$ $\mathrm{mm}$. The division into thirds is applied in the details of the intersecting stone mouldings. Conclusions of the geometrical analysis suggest that the ratio of width to height of the entire portal could be close to 2 : 3 or $5: 8$ to suggest some consideration, but it was not a primary goal to attain precise ratios. The stone cutter just followed many times repeated geometrical procedure - square and the pointed arch, based on it.
\end{abstract}

\section{Keywords:}

Gothic sacral architecture of Slovakia;

Geometrical analysis;

Late gothic stone portal.

\section{Introduction}

Cultural monuments are important part of our legacy documenting to the next generations proofs of skill and the sense of fine art of our ancestors. The older the architecture and its details, forms, and technique used, the richer and broader is our history. Gothic architecture is one of the oldest surviving architecture in Slovakia along with previous fragments and very rarely whole buildings of the medieval Great Moravian Empire (9th - 10th century). Namely finely crafted historic architectonic details are the ones to be more readily compared based on the evolution of forms. Therefore they could be pivotal point in the process of identification of building renovations and extent of various building activities that took place in periods mentioned in archival documents. The late gothic portal was chosen to be analysed also geometrically. Comparison is strictly based on the visible late gothic forms that show similar evolution of architectural details, aesthetic requirements or maybe fashion that found application and similar expression also on the other relatively distant localities. Some of the many analogies could be mentioned (construction, shape of the mouldings etc.): portal of the sacristy, church in Bertesgaden, Germany (dated circa 1500); Parish church of St Stephan in Weiten, Austria (1473); Basilica of the Assumption in Tismice, Czech Republic (1504); Parish church of St Bartolomeo, Czech Republic (1507); The Old castle in Banská Štiavnica, Slovakia (circa 1500), Paulin church in Trebišov, Slovakia (circa 1500), sacristy portal of church in Vinné, Slovakia (1484).

Slovakian territory was a part of the Kingdom of Hungary from the 10th century. During the 15th - 16th century (period to which both late gothic portals could be attributed), the biggest impact had the Battle of Mohács in 1526 between the forces of the Kingdom of Hungary and the Ottoman Empire. The Ottoman victory led to the partition of Hungary for several centuries between the Ottoman Empire, the Habsburg Monarchy, and the Principality of Transylvania. Slovakia remained as a part of the multi-ethnic later 19th century Austro-Hungarian Empire up to 1918.

\section{Church of St Catherine of Alexandria in Handlová}

Handlová is the town with long-lasting mining tradition, situated in the middle of Slovakia, surrounded by mountain ranges. Historically it was known as Cryckershaw (1367), Hemel Lehota (1385), Henellehota (1430), Hendlowa (1571), Kriegerháj, Grägerhaj, Krückerháj, Andreasdorf (1877) 
and Handlová (1920). Hungarian name is Nyitrabánya, German Krieckerhau or Kriegerhay. Handlová is the best known for its coal deposits, exploited from 18th century (written document from 1784).

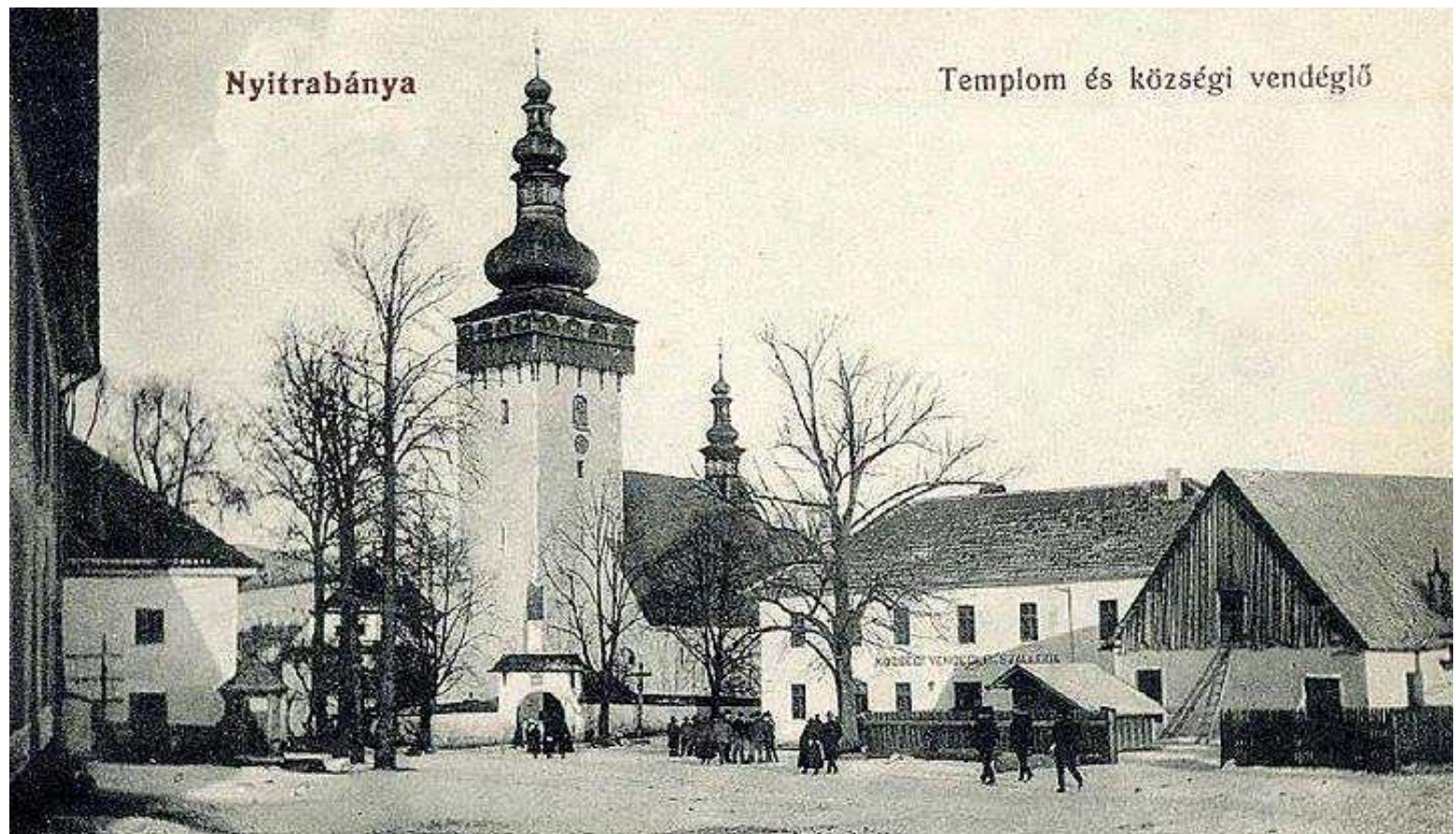

Fig. 1: Handlová, historical postcard, beginning of the 20th century. Source: author's archive.

The municipality was founded by Henrich Kricker (Cricker) in the territory belonging to the Bojnice's estate in previously uninhabited land. The church was apparently built as part of a settlement founded after 1367 [2]. The first mention of the existence of the church of St Catherine of Alexandria comes from 1433 and it was related to the arrival of the Hussites to Handlová [3].

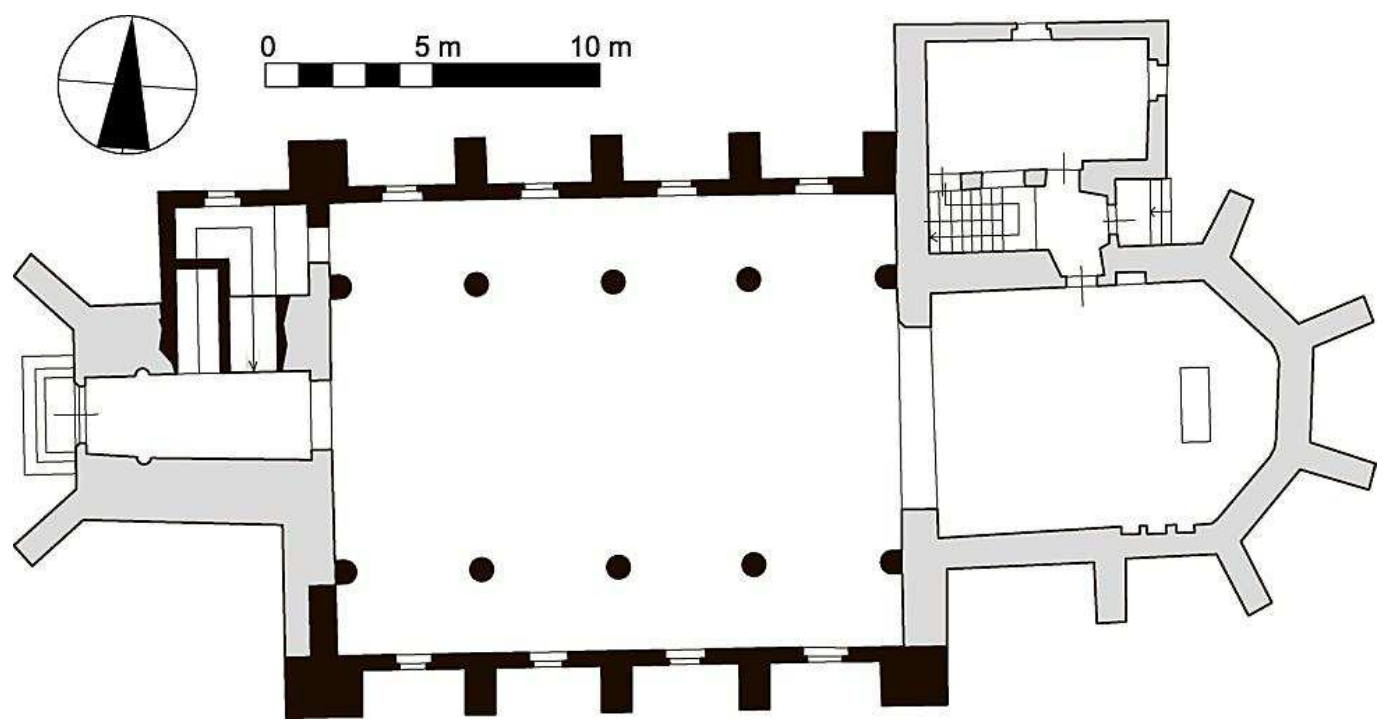

Fig. 2: Handlová, the Church of St Catherine of Alexandria, plan. Black colour denotes the 20th century constructions, built anew after the World War II bombing. Grey colour parts are historical constructions from all previous building stages. There was no precise architectural analysis of the building stages of construction including destructive sounding conducted up to date. This scheme is therefore based on the visual inspection, known written history and historical photographs. Drawing by Z. Grúňová, 2017. 
The Church of St Catherine of Alexandria is a single-nave church building that consists of the six floors high tower on the west side, a nave with built-in galleries and polygonal sanctuary on the east side. The church stands in the middle of the town square between two main roads leading through town. The original fortification wall surrounding church grounds is preserved in fragments; general outline remains visible delineated by the new brick or concrete constructions. Dominant tower with externally projecting wooden gallery on brackets and with baroque onion shaped dome dated to renovations in 1710 and 1755 was recently renovated (2017).

\section{Important construction phases (as identified in [1])}

High Gothic (1360 - 1370). The church was built entirely, including a tower. Several stone details built-in the preserved original masonry of the tower and sanctuary are preserved from this period, e.g. narrow lancet windows without tracery and glass with a plain external chamfering, two gothic stone portals, sedile and stone ribbed vaults in the interior of the sanctuary.

Late Gothic (1502). The church burnt out after the lightning strike in 1500. The damaged nave was newly vaulted with a double rib vault on two central pillars in 1502 [3]. To what extent a tower was damaged cannot be defined. The preserved late gothic stone portal belongs to the late gothic construction phase - maybe original high gothic one was also gravely damaged by fire. Installation of the preserved, present stone portal on the west side of the tower - the main entrance to the building is secondary (mortar used does not fit to the older high gothic stratigraphy of the previous phase).

Later phases. The church was renovated and even dramatically rebuilt in the younger phases. Baroque period added wooden gallery on brackets and onion shaped dome to the tower. The gothic nave was completely demolished and the new one was oriented perpendicularly to the previously long axis of the church in 1940. World War II meant further devastation. Air raid and the bombardment in March 1945 destroyed newly build nave to the rumble. Tower and gothic sanctuary surprisingly remained almost intact. Renovation project from 1947 was not executed; church remained as a ruin up to 1956. Architect Chudomelka tried to recreate extent of the original gothic nave volume and its ground plan outline, set up according to period photographs and traces in preserved gothic plaster, see Fig. 2.

\section{Late gothic portal}

\subsection{Description and preserved condition}

From a typological point of view, it is a relatively popular type of portal, used between 1470 and 1510 under the direct influence of Austrian art. These portals could be found in both church and secular buildings. Pointed arch and mutually intersecting bars create an interesting twist of intersecting curves. This type of portal is also enriched with new elements based on light play. The round base has no compact exterior and its surface is "disturbed" by diamonds - chessboard of squares on which the light is captured in remarkably alternating shadowy parts. 

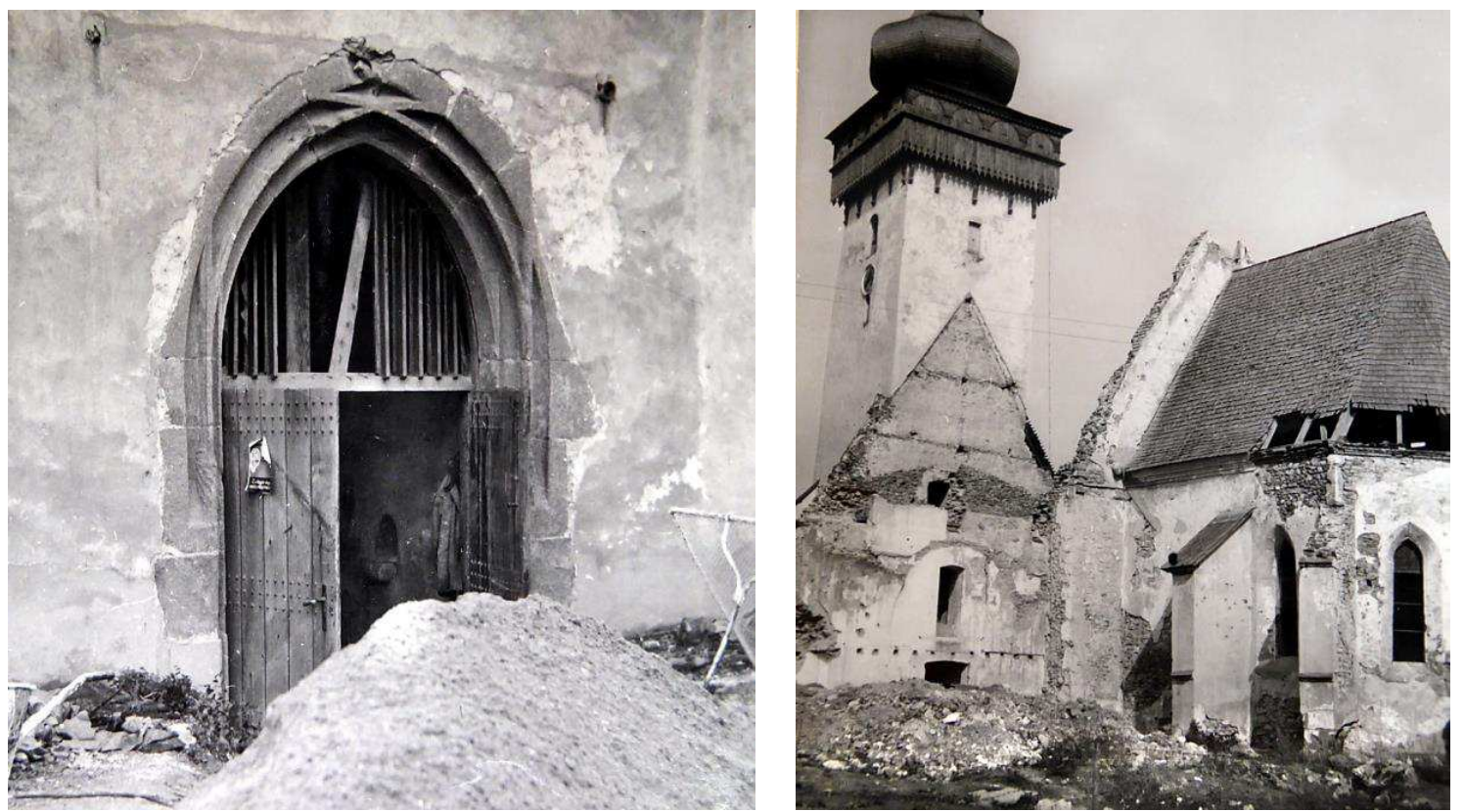

Fig. 3: Handlová, the Church of St Catherine of Alexandria. Left: The stone portal during renovation activities after 1945. Note severe damage of the top keystone and missing profiling of some other stone parts. Right: The extent of bombardment damage, the tower and gothic sanctuary are the only parts to be preserved. The historical roof construction and nave vault dated 1502 remained as a trace in plaster. Source: the Monuments Board of the Slovak Republic archive, used in [1].

The stone portal with a top keystone severely damaged by World War II bombardment was also "redesigned" after 1956 in an incomprehensible way. The restoration was solved by cutting out the entire middle segment about $500 \mathrm{~mm}$ wide and replacing it. Replacement stone is visually different in material, shade of colour, grain, but its overall geometry is totally misunderstood too - the original peak is replaced by a narrower shallow segmented arc. Profiling is partially respected, but this intervention has altered the overall height of the portal. The outer edge of the stone is also largely unusable for shape analysis due to damage and loss of mass in the lower parts, near springline.

The jamb pedestal up to a height of about $1450 \mathrm{~mm}$ is relatively simple - a rectangular crosssection with one concave almost $3 / 4$ circular eyelet at the slightly slanted edge of the corner. Above it are richly profiled jamb mouldings and a plastic diamond pattern with toroid sloping over it. Mouldings, bars are pear shaped in profile. The stone mass of the portal is a light brown-bordo coarse-grained stone made of separate parts deposited on lime mortar, locally unsuitably repaired by cement mortar.

The mass of the stone is currently surface-degraded by weather conditions and wear and local mechanical destruction. The chisel tracks could be noticed with secondary mechanical treatment traces, probably the result of balancing, matching of individual stone parts, as well as a result of renovations - secondary plaster and stone modifications. The trace after insufficient removal of the secondary finishes is located at the arch of the arch, at the top of the portal.

\subsection{Late gothic portal geometry}

Proportions of the late gothic portal parts clearly bear a witness to the geometry concept. Geometry is easy to trace up to springline, but it is partially hypothetic in relation to overall proportions, due to keystone damage / replacement and possible slight displacements of the stones in history (bombardment, load bearing etc.). It is therefore possible only to approximate proportions of width and height of stone portal. Width $A B=2670 \mathrm{~mm}$ to height measured from line $A B$ to the top - outer line of supposed shape of keystone $J$ equal $4100-4200 \mathrm{~mm}$ could be originally a proportion R1 of $2: 3$ (mathematically closer, but historically and more difficult to construct, therefore less probably ratio R2 $5: 8$ ), see Table 1. 
Table 1: Handlová, the late gothic portal. Proportions of width to height.

\begin{tabular}{|l|l|c|c|c|c|}
\hline & \multicolumn{1}{|c|}{ Proportion } & Numeric & Variation to A & Variation to B & Variation to C \\
\hline A & Width $2670 \mathrm{~mm}:$ height $4100 \mathrm{~mm}$ & 0.65122 & - & $+2.44 . \%$ & $+2.27 \%$ \\
\hline B & Width $2670 \mathrm{~mm}$ : height $4200 \mathrm{~mm}$ & 0.63571 & $+2.38 \%$ & - & $-0.17 \%$ \\
\hline C & Ideal geometry w. $2670:$ h. $4193 \mathrm{~mm}$ & 0.63799 & $-2.22 \%$ & $+0.17 \%$ & - \\
\hline R1 & $2: 3$ w. $2670 \mathrm{~mm}:$ h. $4005 \mathrm{~mm}$ & 0.66667 & $-2.37 \%$ & $-4.87 \%$ & $+4.69 \%$ \\
\hline R2 & $5: 8$ w. $2670 \mathrm{~mm}:$ h. $4272 \mathrm{~mm}$ & 0.62500 & $+1.69 \%$ & $+6.25 \%$ & $-1.85 \%$ \\
\hline
\end{tabular}

The bottom part of the portal up to springline is a square $A B C D$ with one side $=2670 \mathrm{~mm}$ being the width of the entire portal. The second side of the square - the height up to the springline is approximately $2620-2670 \mathrm{~mm}$. The entire $A B C D$ square is a $6 \times 6$ composition of the square module of $445 \times 445 \mathrm{~mm}$ or a $3 \times 3$ square module of $890 \times 890 \mathrm{~mm}$.

The portal opening, rectangle $E F G H$ has a width of $1760-1790 \mathrm{~mm}$. Approximation of the opening width to $1785 \mathrm{~mm}$ and springline height to $2670 \mathrm{~mm}$ could be made taking into consideration a ratio of $4: 6$ (module $445 \times 445 \mathrm{~mm}$ ) or $2: 3$ (module $890 \times 890 \mathrm{~mm}$ ). The left jamb AEDH and the right jamb $F B C G$ are both divided into thirds by the stone bars.

The portal opening, rectangle $E F G H$ could be divided into thirds. Each jamb has 5 stone pieces, which are straight; the 6th stone piece above them is already partially curved following the shape of the pointed gothic arch. Intersection of these axes with horizontal line of the horizontal joint between 5th and 6th stone of the jamb creates two centres of the pointed arch. Centre $S 2$ is situated also very nearly to the intersection of the line $A S 2$ (parallel to the portal opening diagonal $E G$ ) and horizontal line put between 5th and 6th stone of the jamb. Centre $S 1$ is close to the symmetrical intersection of $B S 1$ and horizontal joints line. Lines $A S 2$ and $B S 1$ are the only ones, that could be possibly related to ratio $2: 3$ - they are also diagonals of rectangle w. 2670 x h. $4005 \mathrm{~mm}$.



Fig. 4: Handlová, the Church of St Catherine of Alexandria. The late gothic portal (dated 1502), geometrical analysis. Drawing by Z. Grúňová, 2017. 


\section{Conclusions}

The entire portal height, constructed by this "ideal geometrical reconstruction" C, would be 4185 $\mathrm{mm}$. Variations to ratios R1 2: 3 and R2 5:8 are from 2 to $4 \%$. Post-construction deformations of stone positions had to be considered in the cases of proportion ratios $A$ and $B$, meaning that in these portal constructions is not easy to confirm or exclude existence of precise width to height ratio of the whole portal. In ideal geometrical reconstruction $\mathrm{C}$ could these relatively high variations mean that the geometry ratio of the entire width to entire height was not the primary basis for the construction. If the portal geometry was built up from the bottom up, that means from the basis of the square $A B C D$ (and its modules), then jambs were divided into thirds and position of arch circles established on the intersection of the horizontal joints of the stone pieces etc., then entire height of the portal could be result of the geometry of pointed arch plus base square. That means that ratio of width to height could be close to $2: 3$ or $5: 8$ to suggest some consideration, but it was not primary goal to attain these precise ratios, see Fig. 5. The stone cutter just followed common, many times repeated geometrical procedure.

Also modules $890 \times 890(445 \times 445 \mathrm{~mm})$ are not easily applicable to the upper part - the pointed arch. Again this suggests priority of pointed arch construction and square basis to the precise overall ratio.

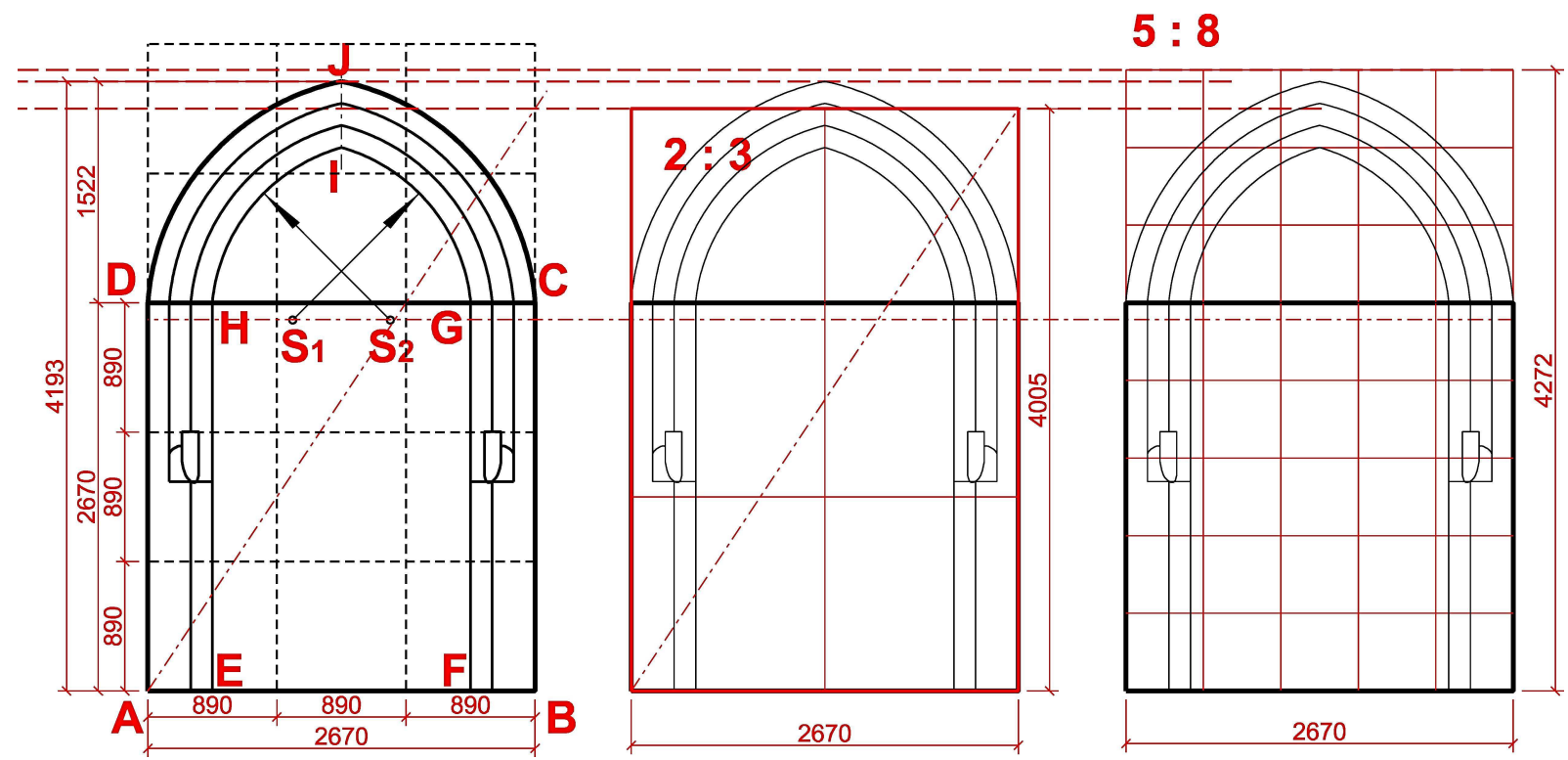

Fig. 5: The late gothic portal (dated 1502), geometrical analysis. Drawing by Z. Grúňová, 2017.

Geometrical analysis of the historical architecture and its details should be the important basis for all renovations. The importance of analysis is increasing in the case of older, very valuable architectural parts. The late gothic stone portal from Handlová church clearly shows the results of the inadequate renovation with misunderstanding of the pointed arch geometry. It is therefore damaging to the effort to preserve cultural monuments and their proper presentation that only in a very small number of cases an interdisciplinary research with the application of geometry to historical structures is carried out. In addition to the older works of Alojz Struhár [4], the only contemporary works in Slovakia are the efforts of several collectives of authors to analyse geometry of the wooden truss structures [5, 6], or the application of geometric structures in the theory of architecture [7].

\section{References}

[1] KOLLÁROVÁ, R.: Architectonic-historical and art-historical research of the Slovak national monument, the Church of St Catherine of Alexandria in Handlová. Unpublished document. Research realized in 2016 - 2017 (in Slovak).

[2] Foundation document of Louis I (Louis the Hungarian) from 8 March 1367, National Archives of Hungary, MNL: DL-104840 (in Latin).

[3] PRÁŠEK M. - TONHAUSER J.: ... I, mining town of Handlová. Neografia a.s., 2000, 9 p. (in Slovak). 
[4] STRUHÁR, A.: Geometrical harmony of the historical architecture of Slovakia. Pallas, 1977 (in Slovak).

[5] AUGUSTINKOVÁ, L. - KRUŠINSKÝ, P. - KORENKOVÁ, R. - HOLEŠOVÁ, M.: Analysis of geometric conception of the historical truss church of All Saints in Vlcovice. IOP conference series: Materials science and engineering, ISSN 1757-8981, Vol. 245, 2017, article No. 042077, 6 p.

[6] KRUŠINSKÝ, P. - AUGUSTINKOVÁ, L. - CAPKOVÁ, E. - KORENKOVÁ, R: Proportions and static analysis of a historical truss in a rural house in Vápenná village. MATEC web of conferences, XXVI R-S-P Seminar 2017 Theoretical Foundation of Civil Engineering, ISSN 2261-236X, Vol. 117, 2017, article No. 00093, 8 p., https://www.matec-conferences.org/articles/matecconf/pdf/ 2017/31/matecconf_rsp2017_00093.pdf.

[7] HOLEŠOVÁ, M.: Ovals in technical practice. Proceedings of the Slovak-Czech Conference on Geometry and Graphics : $26^{\text {th }}$ Symposium on Computer Geometry SCG 2017, 37 ${ }^{\text {th }}$ Conference on Geometry and Graphics, Vršatské Podhradie, September 11 - 14, 2017, ISBN 978-80-86843-57-5, pp. 83 - 88. 